\title{
Surface Karst Landforms of the Notranjska region (south-western Slovenia)
}

\author{
Lukasz Gawor, Iwona Jonczy \\ Silesian University of Technology, Faculty of Mining and Geology, Institute of Applied Geology, \\ ul. Akademicka 2,44-100 Gliwice; \\ e-mail:lukasz.gawor@polsl.pl,iwona.jonczy@polsl.pl
}
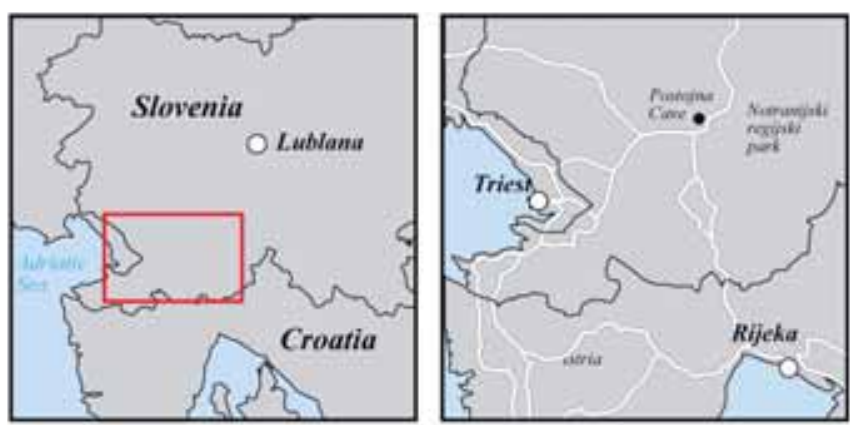

Abstract: The distribution and characteristics of surface karst landforms in the Notranjska region, exemplified in the Cerknisica and Rak river catchment, is presented. The geomorphology of the examined area, with respect to on the micro-, meso- and macroforms division, is described. The course and dynamics of morphogenetic and geological processes are analyzed. A geotourist route linking the described landforms of surface karst is proposed. Key words: landforms of surface karst, polje, karst valley, karst karren, swallow hole, karst spring

\section{Introduction}

The Kras Plateau in Slovenia (area ca $440 \mathrm{~km}^{2}$, length ca $40 \mathrm{~km}$, width ca $13 \mathrm{~km}$ ) constitutes a historical region, where classical forms of karst, both surface and underground, have been recognized and described (Fig. 1).

The name of the region is connected with the term ' $k r a s$ ' (English karst, German Karst, Italian carso), which was first introduced by Jovan Cvijic, a Serbian geographer from the University in Belgrade and the author of the book 'Das Karstphänomen'. Published in 1893, the book was the first to concentrate on karsts, introducing the terminology of karst landforms (Cvijic, 1893). The typology of karst landforms includes macro-, meso- and micro-forms, pertinent to both underground and surface karst (Pulina, 1999).

The Notranjska Region is situated in the Kras Plateau, exactly in the southwestern part of the larger Carniola region. This comprises the Hrušica karst plateau, up to the Postojna Gate, and bordering the Slovenian Littoral - Goriška in the west. The region represents an area where most well-known classical surface karst landforms occur (e.g. poljes, karst valleys, rillenkarren, swallow holes). These forms constitute interesting objects of geological heritage as well as geo-touristic attractions. They might also serve as examples of current morphogenetic processes, which represent geo-touristic phenomena of a dynamic character. Abundance of karst forms, their proximity and accessibility for observation, attracts both scientists and tourists alike. It should be mentioned, that the karst polje and the valley of the Notranjska Region are given as examples of karst phenomena in the book of Pulina and Andrejczuk (2000). This region is also known in the world thanks to its unique Postojna Cave (situated in the neighborhood of the described area), visited by thousands of tourists every year. For these reasons, the Notranjska Region should be under special protection. Moreover, the abandonment of traditional farming in the polje area has been leading to meadows being overgrown by trees. This has influenced the lowering of groundwater level, and, at the same time, reduced surface flooding. As such, flooding grounds may completely disappear. That is the reason, why, in this region of Slovenia, a sustainable and rational land usage is especially important to make sure that agricultural progress does not endanger or allow such unique natural phenomena to be destroyed.

This paper aims to characterize classical landforms of surface karst (based on a literature review), giving their examples in the area under study, describing morphogenetic processes and, finally, correlating the described landforms with human activity, while taking into special consideration their role in the development of geo-tourism in the region.

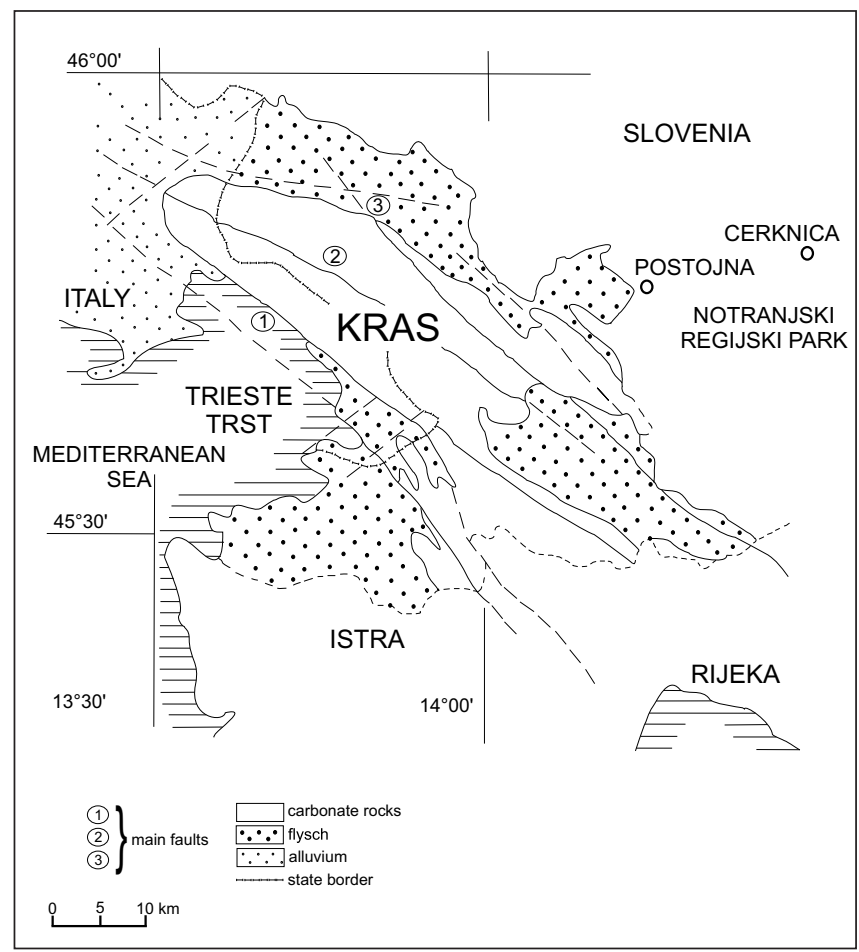

Fig. 1. Location of the Kras Plateau (after Cucchi et al. 1997, modified) 


\section{Surface karst landforms}

\section{Micro-forms}

According to the literature, karst micro-relief develops both on the surface of the karst rocks and beneath soil and plant cover (Pulina, Andrejczuk, 2000). The characteristic surface feature of limestone is its dissection into blocks, called clints, bounded by deep vertical fissures known as grikes. Apart from clints and grikes, limestones also have a number of characteristic surface formations. These are known as runnels, pits and pans. Runnels are gutter-like channels, eroded out of the surface of the limestone, which drain into grikes. Pits and pans are small scale solution features (i.e. formed when water and acids dissolved the limestone) found on tops of the clints. Karren (lapiez) belongs to minor forms of karst, due to the solution of rocks on its surface. These Karren create complexes of superficial micro-solutional features of soluble rocks (Waltham et al., 1997). Karren type relief is represented by linear forms, or, less frequently, oval ones (kamenitze). The micro-forms may be divided into two groups: karren on inclined surfaces and fissure karren. In the first group, the influence of rock structure is hardly visible. In the latter, rock fissures play a decisive role. Karren on inclined surfaces may include, groove karren, rain karren and channel karren (together with a variation of meandrous karren). Structural karren represent a type of fissure karren, which appear on rock outcrops, with layers of slight thickness (Pulina, Andrejczuk, 2000).

In the study area, karren type of micro relief was identified in the region of the Rakov Skocjan gorge (as well as in the whole region), in the form of fissure karren (Fig. 2) and groove karren. (Fig. 3). These forms may be found in the western part of the gorge. The fissure karrens have different dimensions up to $30 \mathrm{~cm}$ in length and several $\mathrm{mm}$ in width. Groove karren may reach the length of a dozen $\mathrm{cm}$ and several $\mathrm{cm}$ in width.

\section{Karst meso-forms - hums and 'karst bridges', karst valleys}

The karst meso-forms include the most characteristic ones: sinkholes (dolines, solution dolines), swallow holes, (occurring in the bottom of the sinkholes), karst hollows (with dimensions of over a hundred meters) and hums. Sinkholes represent depressions in the ground, caused by some form of collapse of the surface layer, which can be linked into uvala or so called badlands. Hums are forms in the shape of residual hills of limestones. Among numerous karst meso-forms in the studied area, we can notice hums with characteristic 'karst bridges' and karst valleys. These forms occur in the area of the Rakov Skocjan gorge (Fig. 4).

Karst hums with interesting rock arches, also called karst bridges, occur in the eastern and western parts of the Rakov Skocjan gorge. In the eastern part of the gorge, the 'Little Bridge' (slov. Malý Most) is situated, which is a karst form that includes fragments of relict underground conduits (Fig. 5). The view from the upper part of the form, available to public via touristic trails with safety barriers, is particularly spectacular. In the western part of the gorge, the 'Big Bridge' is situated. However, it is less accessible and mostly forested, which makes the form described previously decisively more attractive for tourists.

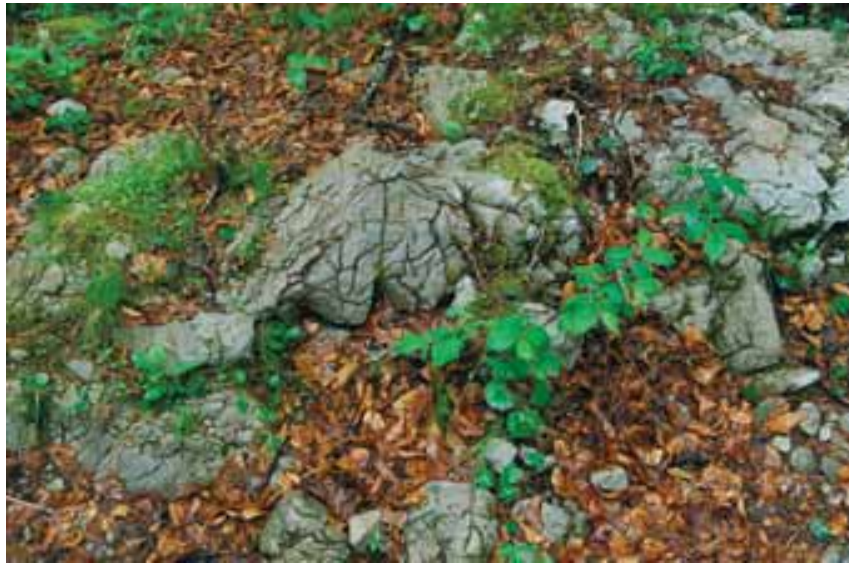

Fig. 2. Fissure karren in the region of Rakov Skocjan, photo Ł. Gawor

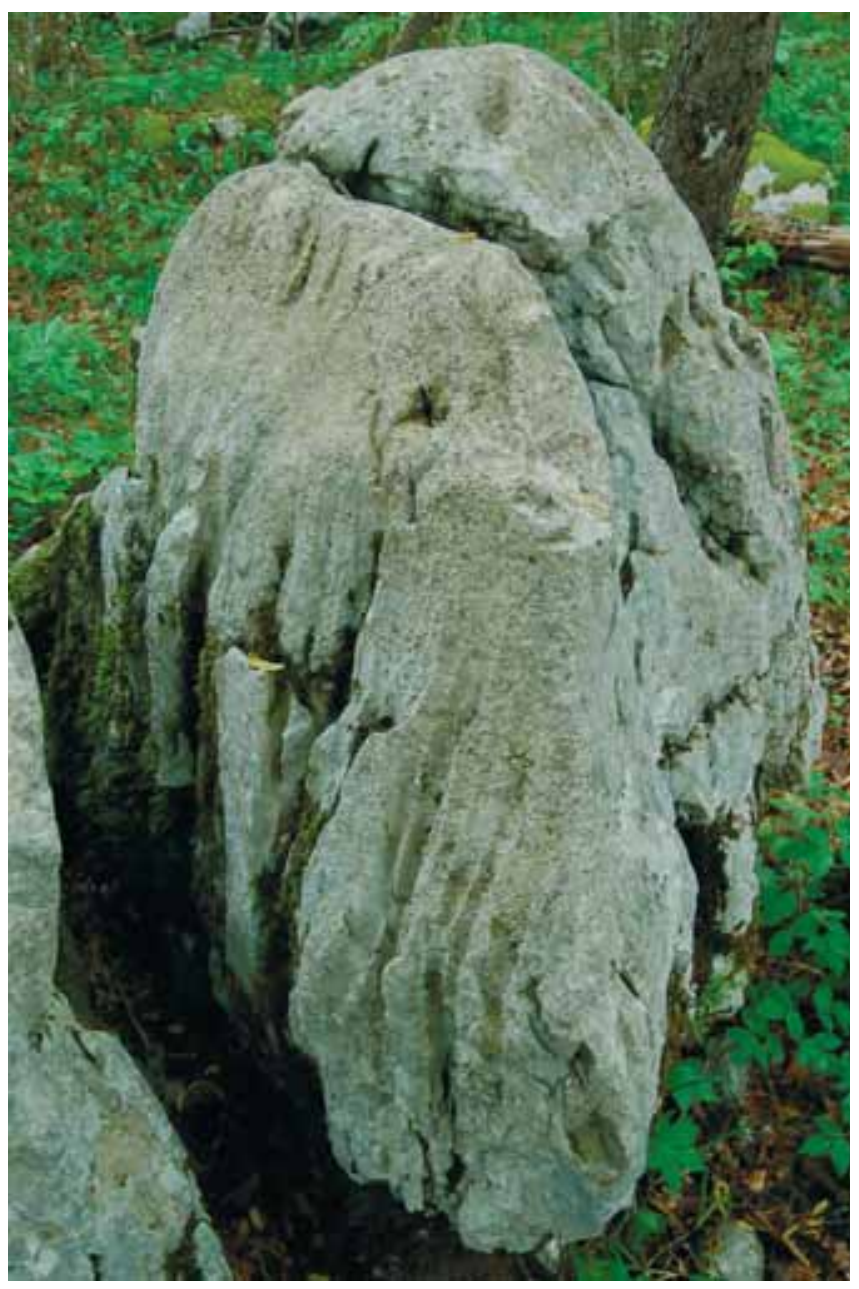

Fig. 3. Groove karren in the region of Rakov Skocjan, photo Ł. Gawor

Another meso-form situated in the Rakov Skocjan gorge is a double blind karst valley. It belongs to fluviokarst mesoforms. The water flowing from one karst spring creates the river which flows in a sinkhole with typical features of a fluvial valley (Figs 6, 7). It is a part of the sinkhole system classified as a double blind karst valley (Habe, 1974). In this area, 14 karst springs with different discharges occur. The Rakov Skocjan gorge is also a typical example of an active collapse doline (Kranjc, 2006). 


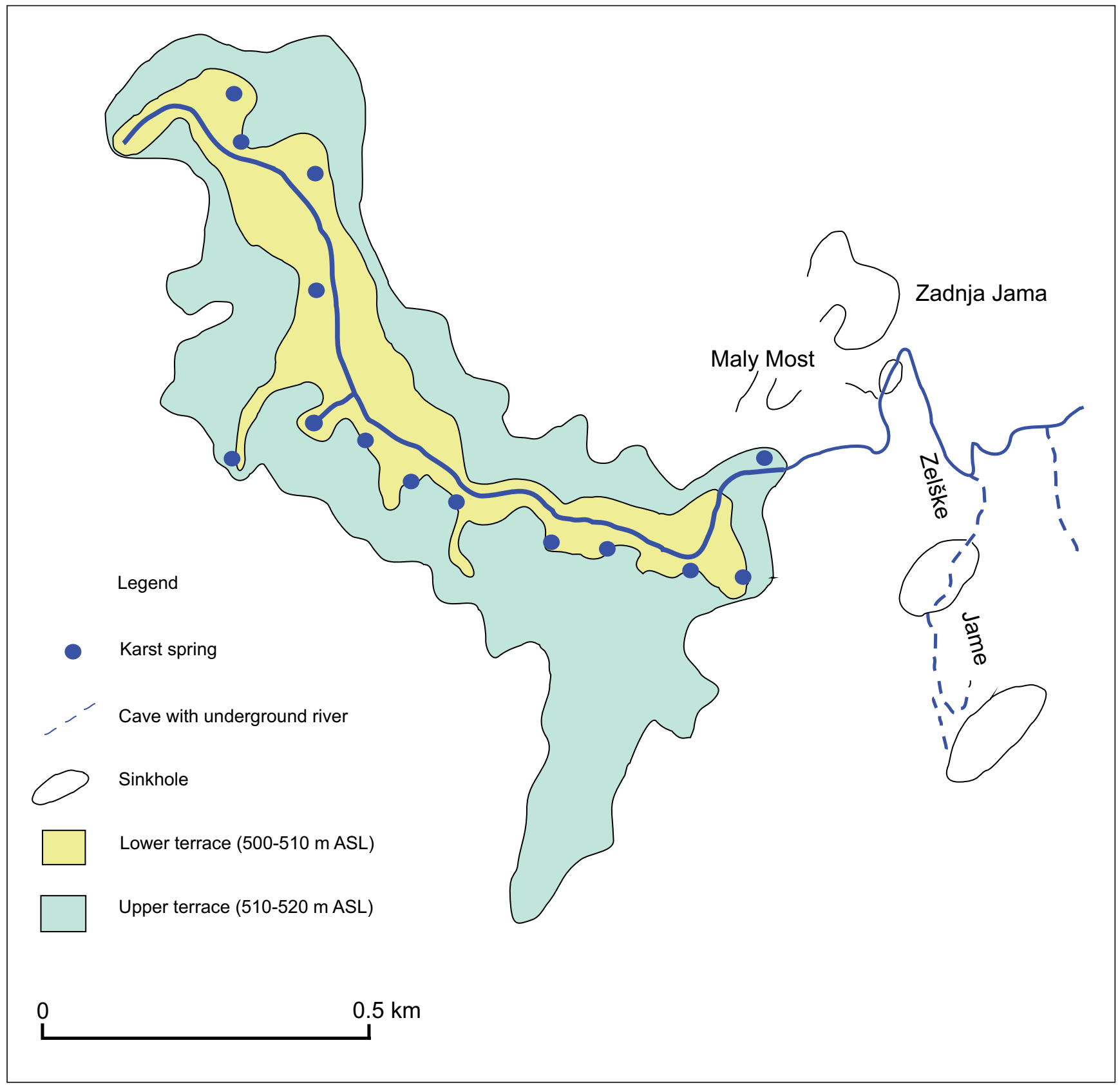

Fig. 4. Karst forms in the gorge of Rakov Skocjan (after Pulina 2000, modified)

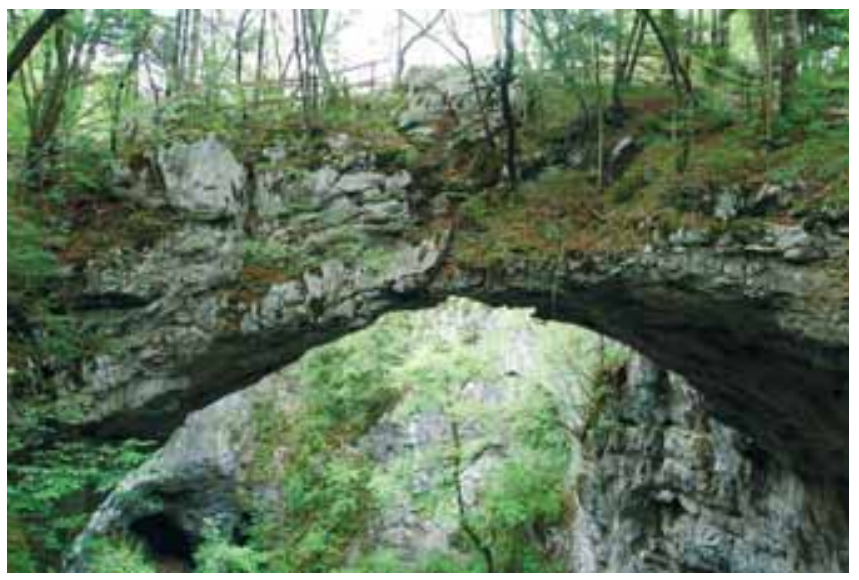

Fig. 5. Karst meso-form - 'Little Bridge', Slovenian Malý Most in the Rakov Skocjan gorge, photo Ł. Gawor

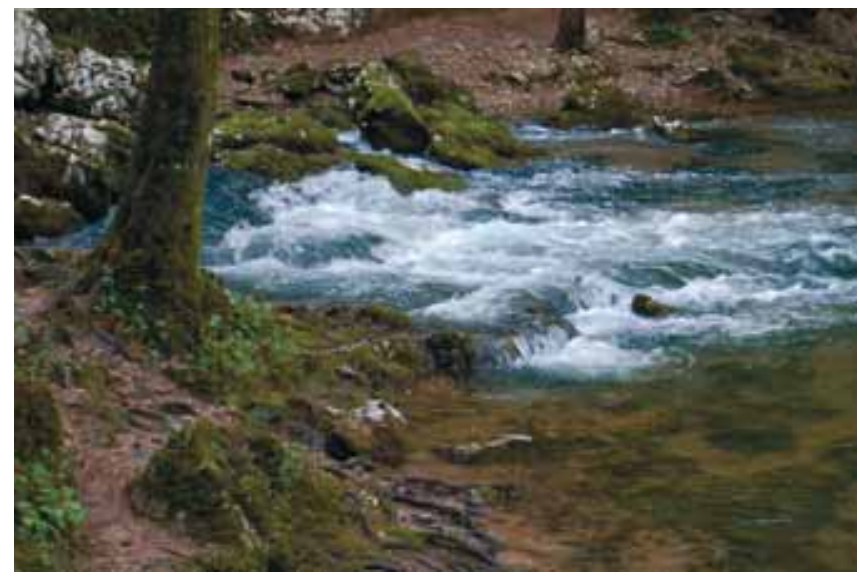

Fig. 6. Head fragment of karst valley with the karst spring in the Rakov Skocjan gorge, photo Ł. Gawor 


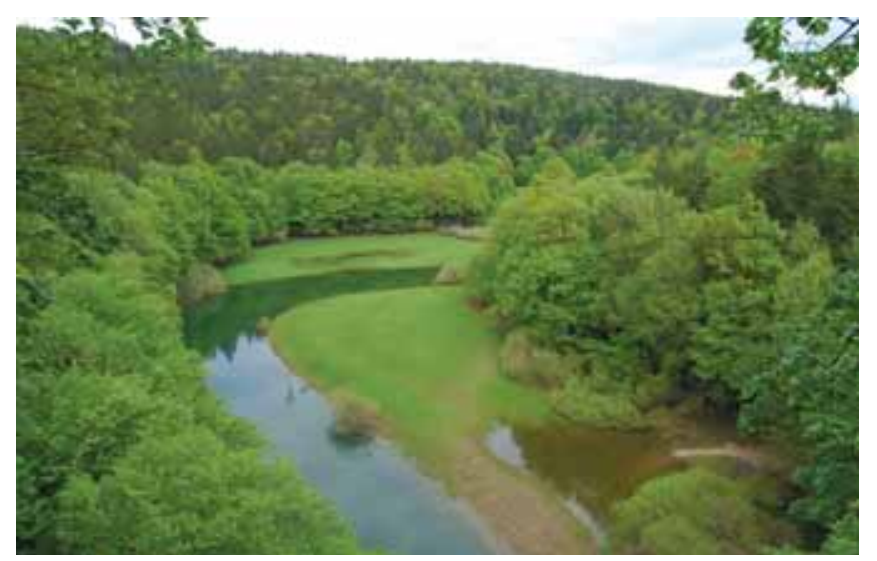

Fig. 7. Karst meso-form - karst valley, Rakov Skocjan area, photo Ł. Gawor

The valley head (the zone around the karst spring) is subjected to constant transformation, as a result of the processes of head-ward erosion and chemical denudation. An observation of water flow from the karst spring combines both perceiving the form's shape and experiencing the so-called geo-touristic phenomenon.

\section{Karst macroforms - poljes}

Polje represents one of the classical examples of karst macroforms. According to the usual definition, 'a polje is defined as a great karst closed basin, with a flat bottom, karstic drainage and steep peripheral slopes` (Gams, 1974). Apart from classical polje, there is also semi-polje (border polje), situated on the place of contact with non-karstic rocks, as well as hanging or inactive (dry) polje (Pulina, Andrejczuk, 2000). In the Dinaric karst, there is a wide range of poljes, e.g. open poljes, partly drained by a permanent or intermittent streams, or paleo-poljes, which may be filled by deposits coming from the weathering of the slopes (Nicod, 2003). Polje (which in Slovenian means 'field') originates in a regional karst hydrographic network, closely connected with the system of underground water drainage. The slopes of poljes are often steep. Ariver crossing the polje has its origins in karst springs and ends in swallow holes. During high levels of water, a part of polje may be flooded, making a periodic lake. This is connected with a limited capacity of swallow holes. Good soil conditions (mainly azonal alluvial soils) and adequate humidity of polje bottoms foster the development of agriculture in these areas.

The Cerkniško Polje, situated in the described region is periodically filled with water from the Cerknica Lake. The Cerknica Lake (Cerkniško Jezero in Slovenian) is situated within the southern part of this polje. The polje has been in the centre of interest of scientists for centuries, first mentioned in 1689, in a description by Janez Vajkard Valvasor (Shaw, 2010).

Cerkniško Polje is situated in the Notranjska region, between the villages of Cerknica, Zerovnica, Gorenje Jezero and Dolenje Jezero. The NW-SE orientation of the landform is related to the extension of the Dynarides. The polje is surrounded by the Javornik Hills (reaching the height of $1268 \mathrm{~m}$ asl) and Slivnica (1022 $\mathrm{m}$ asl), both belonging to the range of the Dinaric Mountains. The Cerkniscica river Catchment covers the surface of about $475 \mathrm{~km}^{2}$.

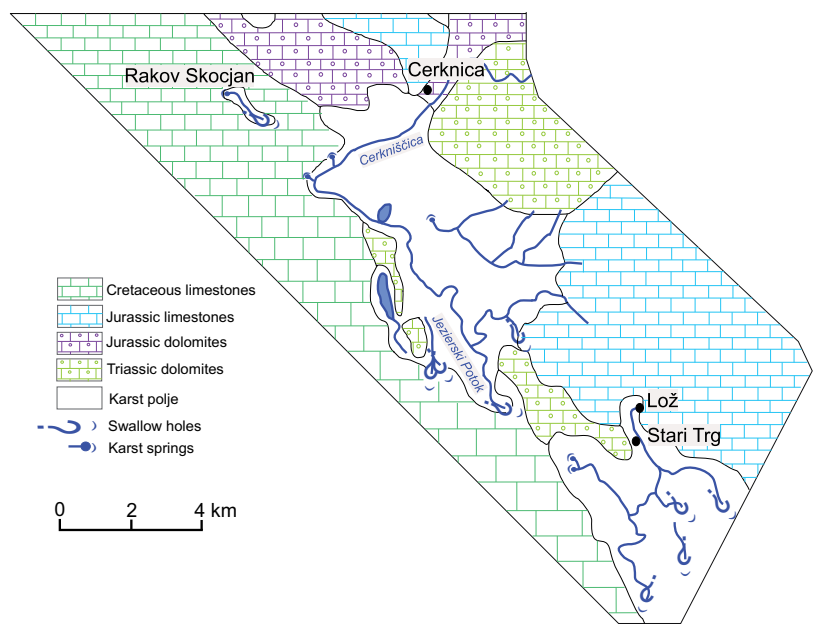

Fig. 8. Geological map of the Cerknica area (after Pulina 1974, modified)

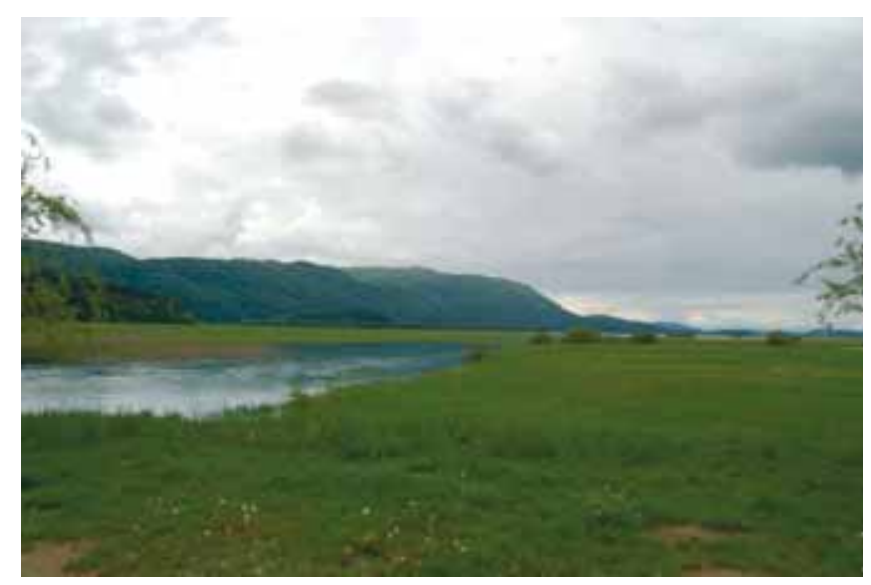

Fig. 9. Cerkniško Polje, view from the north side, photo Ł. Gawor

The surface of the lake oscillates between $28 \mathrm{~km}^{2}$ and $38 \mathrm{~km}^{2}$, and the water level reaches altitudes from 546 to $551 \mathrm{~m}$ asl. In the basement, there are mainly dolomites (Jurassic and Triassic) and limestone (Jurassic and Cretaceous). Karst springs feeding the lake are situated in the south-eastern part of the polje (Figs 8, 9, 10). The flat bottom of the described karst landform is regularly flooded during autumn and spring periods for several months.

The main swallow holes are situated in the north-western part of the landform (Cucchi et al., 1997; Kovačič, 2010) (Figs 9, 10). Depending on the season and the level of water in the polje, tourists can experience completely different landscapes. In this case, one can also observe the 'geotouristic phenomena', although these appear rarely. For example, in the spring, when the polje area may be filled with water within a dozen of hours. When the lake is fully filled, it covers an area of $38 \mathrm{~km}^{2}$, and is one of the biggest lakes in the country. The lake grows also in the late autumn, when heavy rain substantially exceed the capacity of swallow holes, and the water level stays high until June. In the summer period, during torrential rains, the water level also rises. At this point the lake becomes a fishing place, where the Slovenian Fishing Association has its fishing grounds. 


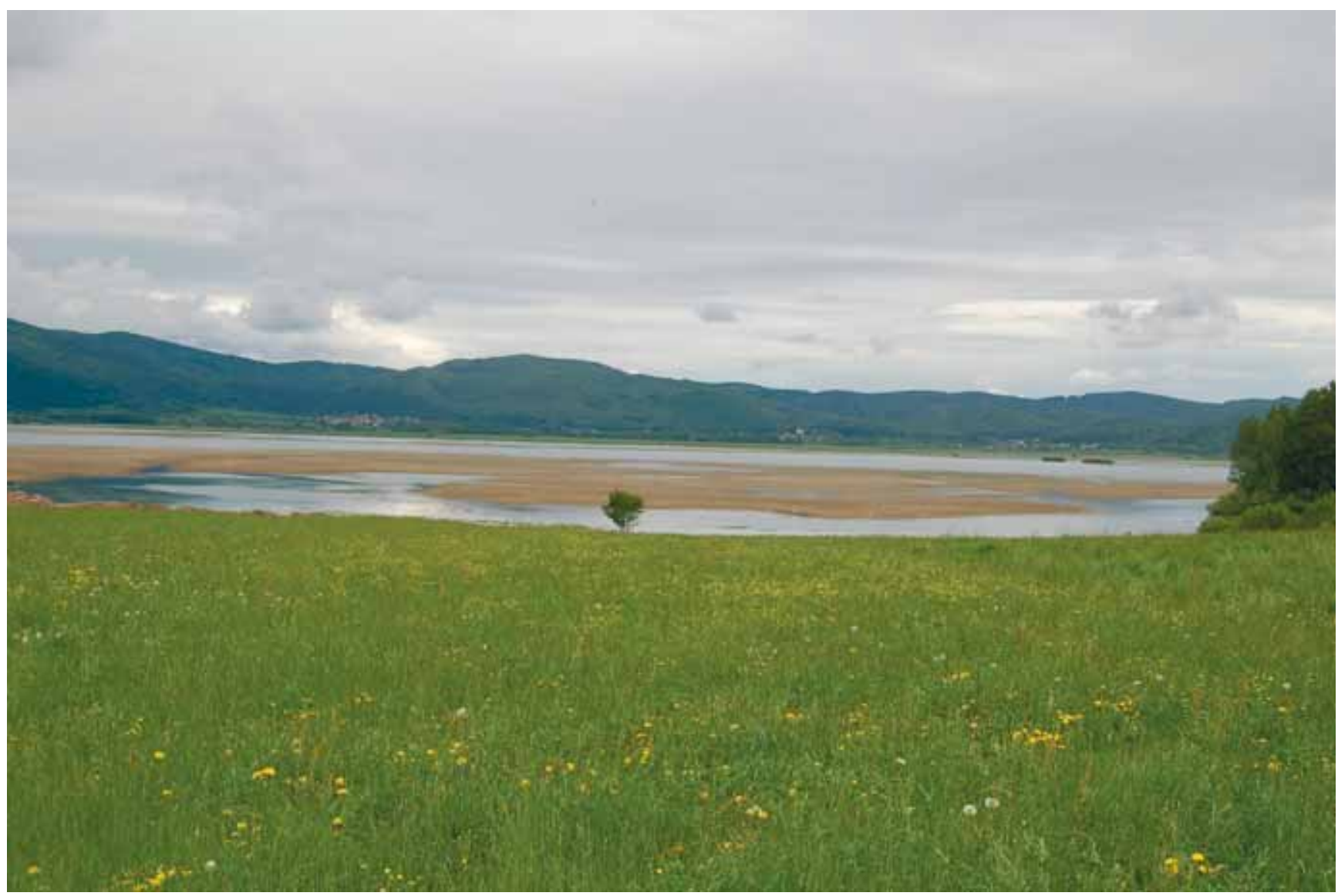

Fig. 10. Cerkniško Polje, panorama of the surrounding area of Gorne Jezero, photo Ł. Gawor

\section{Suggestion of a geotouristic trail}

The Cerknica area, together with the surrounding areas, offer wide opportunities for the development of geotourism. An example of a geotouristic trail may include the following landmarks: Cerknica - Gorenje Jezero Village - Otok - Dolenje Jezero Village - Dolenja Vas - Rakov Skocjan. The distances between the successive trail stages may be covered by car or bike, to reach the final destination - the Rakov Skocjan gorge, which must be crossed on foot (Fig. 11).

The distance between the Cerknica town (point 1, Fig. 11), which is the beginning of the route, and the next stage marked by the Gorenje Jezero village is ca. $12 \mathrm{~km}$ (point 2, Fig. 11). The distance from Gorenja Vas to Rakov Skocjan is $18 \mathrm{~km}$, and there are stops on the way in Otok and Dolenje Jezero (points 3-5, Fig. 11).

The best starting point is Cerknica, which is the capital of the administrative district of the same name. This small town, situated in the area abundant with geological phenomena, constitutes a perfect place to plan tourist routes, and serves as a good accommodation spot.

The first geotoristic site is the karst polje - Cerkniško Polje, periodically filled with the water of the Cerknica Lake, situated between Cerknica, Zerovnica, the Gorenje Jezero Village and the Dolenje Jezero Village.

From Cerknica, there is a road around the lake available for traffic, which makes possible driving along the whole area covered by the lake. The smaller villages passed on the way, like the Gorenje Jezero village, Otok, the Dolenje Jezero village or Dolenja Vas, are situated directly on the Cerkniscica River and serve as rest areas, from which the state of the lake and the surrounding nature can be observed.

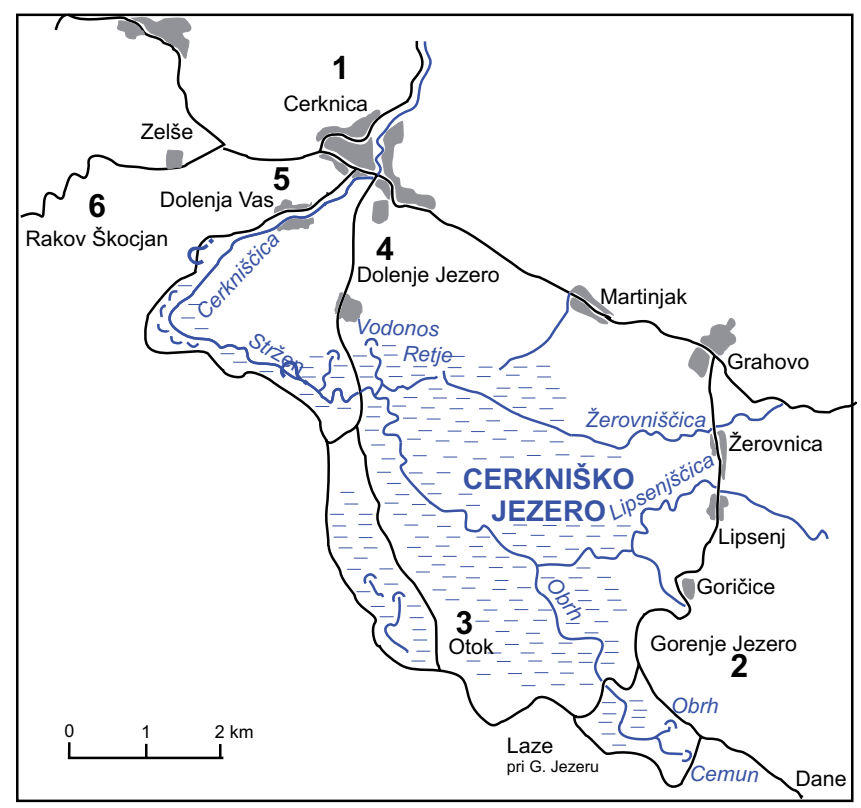

Fig. 11. Sketch of the Lake Cerknica region, with marked points of the geotouristic trail Explanations: 1-6 landmarks of the geotouristic trail (http://www.ribiska-zveza.si/) 
The Gorenje Jezero and Otok are small villages with unforgettable views of the lake. In the southwest part of Gorenje Jeziero, a church is situated, which belongs to the Parish of Stari Trg pri Ložu. These place are the most attractive for observation of the lake and its changing water levels, as well as the areas showing the richness of flora characteristic for a lake habitat.

The Dolenje Jezero Village is worth a longer visit, where tourists can visit a small museum (Museum of Lake Cerknica - Muzej Cerkniskega Jezera) with a moving lake model showing exactly how the whole hydrological system of the basin works.

In Dolenja Vas, it is recommended to visit the St. Laurentius Church, belonging to the Cerknica Parish. The church dates back to 1616 and boasts a gold-plated altar dedicated to St. Margaret.

The last stage of the trail is Rakov Skocjan gorge (point 6, Fig. 11), where at the distance of $6 \mathrm{~km}$, there is a complex of karst landforms, among which the Little and Big Bridges, karren (e.g. on bare rock surface of the gorge slopes), karst springs and valleys are worth particular attention. The Rakov
Skocjan Regional Park is the oldest landscape park in Slovenia, under protection since 1949. In the gorge, there are information panels, which on the stretch of $2,5 \mathrm{~km}$ provide a natural trail with an educational and touristic character.

\section{Summary}

The activity of the Cerknisica and Rak rivers contributed to the creation of a unique karst landscape in the Notranjska area, where, within a relatively small surface, examples of karst micro-, meso- and macro-forms can be observed. The most attractive landforms represent karren (fissure karren and groove karren), forms of rock bridges, swallow holes, karst springs, karst valleys and poljes. Here, it is possible to observe not only karst landforms, but also geological processes, e.g. changes of the water level of the Cerkniško Polje. This is also an area of a regional park, due to unique habitats of a wide spectrum of plant and animal species.

These factors demonstrate that the described region has great potential to for the development geotourism.

\section{References}

Cucchi F., Mihevc A., Ferrarese F., Sauro U., 1997. Classical karst. Supplement Geografia Fisica e Dinamica Quaternaria, 11/2. Fourth International Conference on Geomorphology, Italy: 167-180.

Cvijic J., 1893. Das Karstphanomen. Geografische Abhandlungen von Albrecht Penck 5 (3).

Gams I., 1974. Kras. Izdala Slovenska matica, Ljubljana.

Habe, F., 1974. Nekaj o začetkih slovenskega speleološkega izrazoslovja. Naše jame, 15: 11-115.

Kovačič G., 2010. An attempt towards an assessment of the Cerknica Polje water balance. Acta Carsologica 39/1: 39-50.

Kranjc A., 2006. Some large dolines in the Dinaric karst. Speleogenesis and Evolution of Karst Aquifers, 4 (1): 4

Nikod J., 2003. A little contribution to the karst terminology: special or aberrant cases of poljes. Acta Carsologica, 32/2, 3: 29-39.

Pulina M., 1999. Kras. Formy i procesy. Wydawnictwo Uniwersytetu Śląskiego, Katowice.
Pulina M., Andrejczuk W., 2000. Wielka encyklopedia geografii świata, t. XVII Kras i jaskinie. Wydawnictwo Kurpisz, Poznań.

Shaw T., 2010: Aspects and the history of Slovene Karst, 1545-2008. Karst Research Institute at ZRC SAZU, Ljubljana.

Waltham A.C., Simms M.J., Farrant A.R and Goldie H.S., 1997. Karst and caves of Great Britain. Geological Conservation Review, 12, JNCC, Chapman and Hall.

\section{Websites}

www.park-skocjanske-jame.si

http://life.notranjski-park.si/eng/project threats.shtml

http://www.ribiska-zveza.si

http://www.visitslovenia.pl/o_slowenii/42,267,0,0,Cerknica+i+Jezioro+ Cerknickie

http://navtur.pl/place/show/3328,jezioro-cerknickie 